\title{
Haemolytic-uraemic syndrome
}

\section{Epidemiological and clinical study}

\author{
P. M. V. vaN WIERINGEN, L. A. H. MONNENS, and E. D. A. M. SCHRETLEN \\ From the Paediatric Department, University of Nijmegen, the Netherlands
}

\begin{abstract}
van Wieringen, P. M. V., Monnens, L. A. H., and Schretlen, E. D. A. M. (1974). Archives of Disease in Childhood, 49, 432. Haemolytic-uraemic syndrome: epidemiological and clinical study. Between January 1965 and December 1970, 212 patients with the haemolytic-uraemic syndrome in the Netherlands were analysed in an epidemiological and clinical study of the disease. The disorder typically occurs in early infancy, in children without antecedent illness. The majority of the patients were younger than 4 years. The incidence of the disease in the Netherlands is increasing. The disease occurs throughout the year but peak incidences were noted during the late spring and early summer. Apart from this seasonal influence there was a geographical clustering. The possible relation of the epidemiological features of the syndrome to a viral aetiology is discussed.
\end{abstract}

The haemolytic-uraemic syndrome (HUS), first described by Gasser et al. (1955), is characterized by acute haemolytic anaemia, thrombocytopenia, and renal failure. There have been many subsequent reports of individual cases, large series (Davies, 1968; Gianantonio, Vitacco, and Mendilaharzu, 1967; Gianantonio et al., 1964, 1968; Habib, Mathieu, and Royer, 1967; Kaplan et al., 1971; Kibel and Barnard, 1968), and epidemics (Barnard and Kibel, 1965; Gianantonio et al., 1964; McLean, Hilton Jones, and Sutherland, 1966; Ruthven and Fyfe, 1968) from various parts of the world. Despite the extensive published reports, epidemiological information remains sparse and the nature of the disease purely conjectural.

The purpose of this report is to summarize the epidemiological data and clinical characteristics from a study of 212 children with HUS in the Netherlands between January 1965 and December 1970.

\section{Materials and methods}

This retrospective analysis has been made possible by the co-operation of $96 \%$ of the paediatricians with a clinical practice in the Netherlands between January 1965 and December 1970. We have personally seen all case histories and clinical data. A case was accepted as HUS if the four following conditions were met. (1) A history of a prodromal illness in which gastrointestinal or respiratory tract symptoms were present. (2) A major

Received 28 November 1973. illness with signs of haemolytic anaemia: lowering of $\mathrm{Hb}$, raised reticulocyte counts $(>1.5 \%)$, decreased free haptoglobin, and characteristic red cell morphological changes. (3) Evidence of localized intravascular coagulation: thrombocytopenia (platelets $<100,000 /$ $\mathrm{mm}^{3}$ ) or other signs as, for example, a rise in fibrinfibrinogen related antigen. (4) Demonstration of renal failure: raised blood urea $(>30 \mathrm{mg} / 100 \mathrm{ml}$ ) with oliguria (urinary output $<200 \mathrm{ml} / \mathrm{m}^{2}$ per $24 \mathrm{hr}$ ) or anuria (urinary output $<15 \mathrm{ml} / 24 \mathrm{hr}$ ).

Ten cases were included in the study, though they fulfilled only three out of the four criteria, since the clinical picture was highly suggestive of HUS. Thus, 8 cases had normal $\mathrm{Hb}$, but had a raised reticulocyte count, and 1 patient, in addition, had a much reduced free haptoglobin. In 4 other patients Burr cells were present in the blood picture, and the free haptoglobin level was reduced in the 2 in which it was measured. 3 other patients had been given a blood transfusion elsewhere, so that the initial $\mathrm{Hb}$ level was not known. 2 children without uraemia had haematuria and severe proteinuria.

\section{Results}

General findings. From January 1965 until December 1970 data were collected for 212 cases. Fig. 1 shows the number according to the year of onset.

The ages of the 212 children ranged from 1 month to 14 years, mean 23 months. The age of onset is shown in Fig. 2. Of the 212 children, 183 were less than 48 months. In 132 cases out of the 198 where the family pattern was known, the patient was the youngest of the family. No difference in sex 


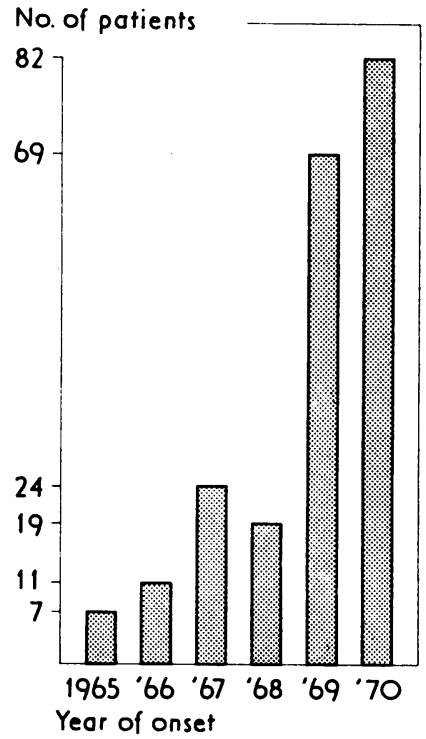

FIG. 1.-212 children with the haemolytic-uraemic syndrome according to year of onset.

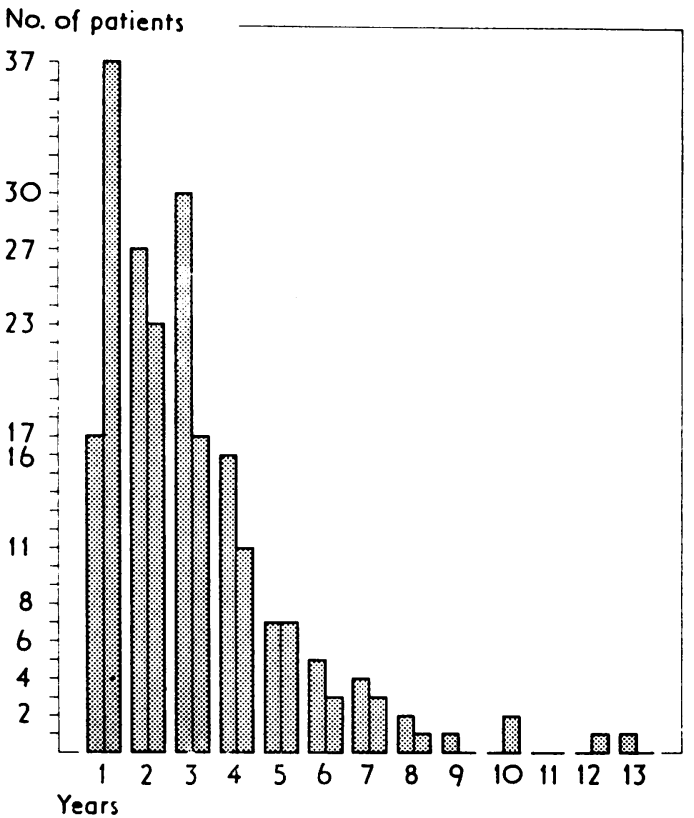

FIG. 2.-Age of onset of the haemolytic-uraemic syndrome in 212 children.

incidence was noted, 107 were male and 105 were female.

The majority of patients (186 of 198) were previously healthy. 5 children had a disorder of the nervous system, 3 psychomotor retardation of unknown origin, 1 cerebellar ataxia, and 1 epilepsy. 1 patient had bronchial asthma, 1 ventricular septal defect, and 1 a neuroblastoma. We found 1 patient with a duplex kidney. The youngest patient was a 25-day-old premature baby.

No blood or renal disorders were found in relatives of the patients. Gastroenteritis was present in 1 or more of the patient's family in 49 cases, and in 14 cases there were patients with gastroenteritis in the neighbourhood.

Prodromal illness. The disease began in a previously healthy child. The most common initial symptom was diarrhoea which occurred in 157 $(88 \%)$ of 198 patients. In 70 of these the diarrhoea was bloody. Vomiting was the first sign in 18 patients (9\%) and abdominal pain in $5(2 \%)$.

During the prodromal phase (Fig. 3) diarrhoea $(91 \%)$ and vomiting $(80 \%)$ were the outstanding symptoms. The frequency of bloody diarrhoea $(66 \%)$ was striking, and 7 patients had laparotomies for suspected intussusception. 1 patient had a rectal biopsy for suspected ulcerative colitis. Bleeding into skin (excluding petechiae in 12 cases) or urinary tract was infrequent (19 cases). Fever was usually absent and never exceeded $38.5{ }^{\circ} \mathrm{C}$. Infections of the respiratory tract were uncommon (14 cases).

The mean interval from onset of the prodromal illness to onset of the second phase of the illness in 198 cases was 6 days, with a range from 1 to 15 days. The prodromal phase was usually followed by the sudden development of the major illness, a latent period between the two stages of the syndrome being uncommon.

Because the multiple disturbances in HUS require prompt treatment (Lieberman, 1972; Monnens et al., 1972), we noted the time between onset of the prodromal phase and hospitalization, and the reason for admission. Within the first 6 days of the disease $128(67 \%)$ of 198 patients were admitted to hospital, and $154(86 \%)$ patients were admitted within 8 days. In $62(31 \%)$ the reason for admission was gastroenteritis which had failed to respond to usual therapy. In $47(24 \%)$ decreased urinary output or anuria was the admission diagnosis. Sudden onset of pallor was the reason in $36(18 \%)$ and bleeding manifestations in $19(10 \%)$. In $19(10 \%)$ drowsiness or irritability was prominent. In only 8 (4\%) had seizures occurred.

Major illness. On initial examination the majority of patients were pale. The blood pressure was usually normal at first, but was often raised later (in 93 of 212 patients), particularly in severe cases 


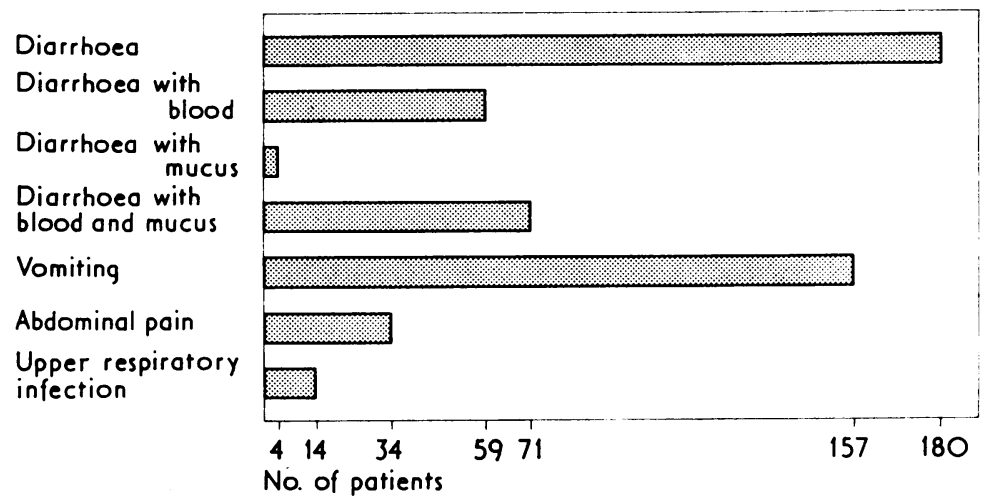

FIG. 3.-Symptoms in the prodromal phase in 198 children with the haemolytic-uraemic syndrome.

(Rubin, 1964). Oedema and hepatomegaly were common. Disturbances of the CNS (seizures, stupor, coma, or paresis) were infrequent, other than in the most severe cases (12 cases of anuria who recovered, and 18 cases in the terminal phase of the disease).

A lowered $\mathrm{Hb}$ was a consistent finding. Reticulocyte counts exceeded $5 \%$ in $53 \%$ of cases. The peripheral blood showed the characteristic picture of red cell fragmentation in the 133 cases so examined.

Free haptoglobin was low or absent when it was measured. Thrombocytopenia was usually present; in 151 cases $(76 \%)$ it was $<50,000 / \mathrm{mm}^{3}$. Coagulation investigations were done in few patients, but when done they confirmed the findings of others (Avalos et al., 1970; Monnens et al., 1972). Proteinuria and (usually microscopical) haematuria were present in all patients.

Blood urea levels were $>300 \mathrm{mg} / 100 \mathrm{ml}$ in 107 cases $(50 \%)$ and $100-300 \mathrm{mg} / 100 \mathrm{ml}$ in 80 cases $(38 \%)$, only 2 cases having no raised blood urea. Anuria was present in 100 patients ( $48 \%$ ), oliguria in $43(21 \%)$, and a normal urinary output in $64(31 \%)$. Urinary output was unknown in 5 patients who died on the day of admission. 26 deaths occurred in 100 patients who showed anuria. The overall mortality was $16 \%$ (33 patients). The outcome of the patients with anuria related to age is shown in Table I.

Bacteriological and viral investigations. These were carried out in 143 patients, in 84 patients bacterial studies only, in 25 patients viral only, and in 34 patients both (Table II).

In 13 patients a significantly increased viral antibody titre was detected, 3 of these relating to an adenovirus. In all 13 cases the virus was also
TABLE I

Deaths in 100 children with anuria

\begin{tabular}{c|c|c}
\hline Age (yr) & $\begin{array}{c}\text { No. of patients } \\
\text { with anuria }\end{array}$ & No. of deaths \\
\hline 0 & 17 & 9 \\
1 & 31 & 8 \\
2 & 19 & 1 \\
3 & 16 & 2 \\
$4-5$ & 10 & 5 \\
$\geqslant 6$ & 7 & 1 \\
\hline
\end{tabular}

TABLE II

Microbial investigations in 212 children with haemolytic-uraemic syndrome

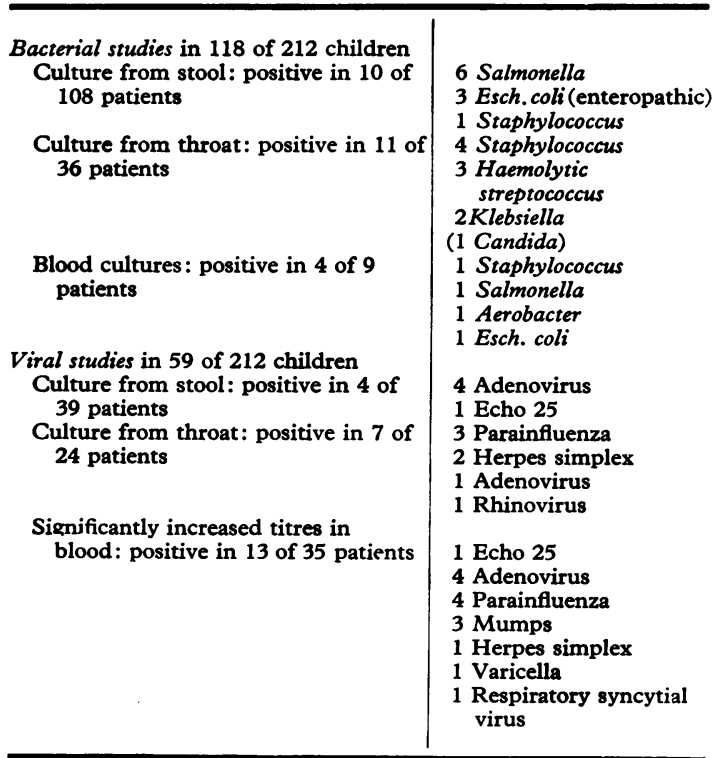


isolated from stools and in 1 of them from the throat as well. 1 patient had increased titre against adenovirus and ECHO 25, and both viruses were isolated from the stool. 4 other patients had increased titre against parainfluenza, and in all the virus was cultured from the throat. Significantly increased titres for mumps were found in 3 patients, for respiratory syncytial virus in 1 , and 1 patient had an increased titre against varicella and herpes simplex, the herpes virus being isolated from the throat.

In addition to the 2 patients already mentioned with a dual infection, a third patient had an increased titre against herpes simplex, with throat cultures positive for herpes simplex and Candida.

Epidemiological findings. Many of the patients received a variety of drugs during the prodromal phase of the disease, mostly antibiotics and antidiarrhoeal agents, but none were felt to play a role in the initiation of the illness. None of the patients had been exposed to toxic substances (Olson et al., 1971; Wolman, 1972). No relation between immunizations and the illness was apparent (Brain, 1969; Dosik and Tricarico, 1970; Mathieu et al., 1969).

Data concerning annual and seasonal incidences are presented in Fig. 4. An increase in the incidence was noted in 1969 and 1970, with peaks occurring in the period from April to July (late spring and early summer months).

In 6 cases 2 children in a family suffered from HUS at the same time (Anthony and Kaplan, 1968; Campbell and Carré, 1965). In addition, we noted that in 11 cases a cluster of 2 or 3 cases occurred within small villages. But we could not show that in any particular year there was an undue incidence of HUS in any of the 11 provinces of the Netherlands.

\section{Discussion}

In the few years since widespread attention was drawn to HUS, the number of recognized cases has increased greatly (Gasser et al., 1955; Gianantonio et al., 1964; McLean et al., 1966; Kaplan et al., 1971). We also found a significant increase in the Netherlands; and it is greater than would be expected on the basis of an increase in the diagnosis of the syndrome. A retrospective study of the archives of our clinic tends to support this fact: 4 cases of the disease were discovered in retrospect during the years 1959-1964, while in the period analysed (1965-1970) 50 patients with HUS were admitted to our clinic. That the syndrome has not been neglected formerly agrees with the findings of

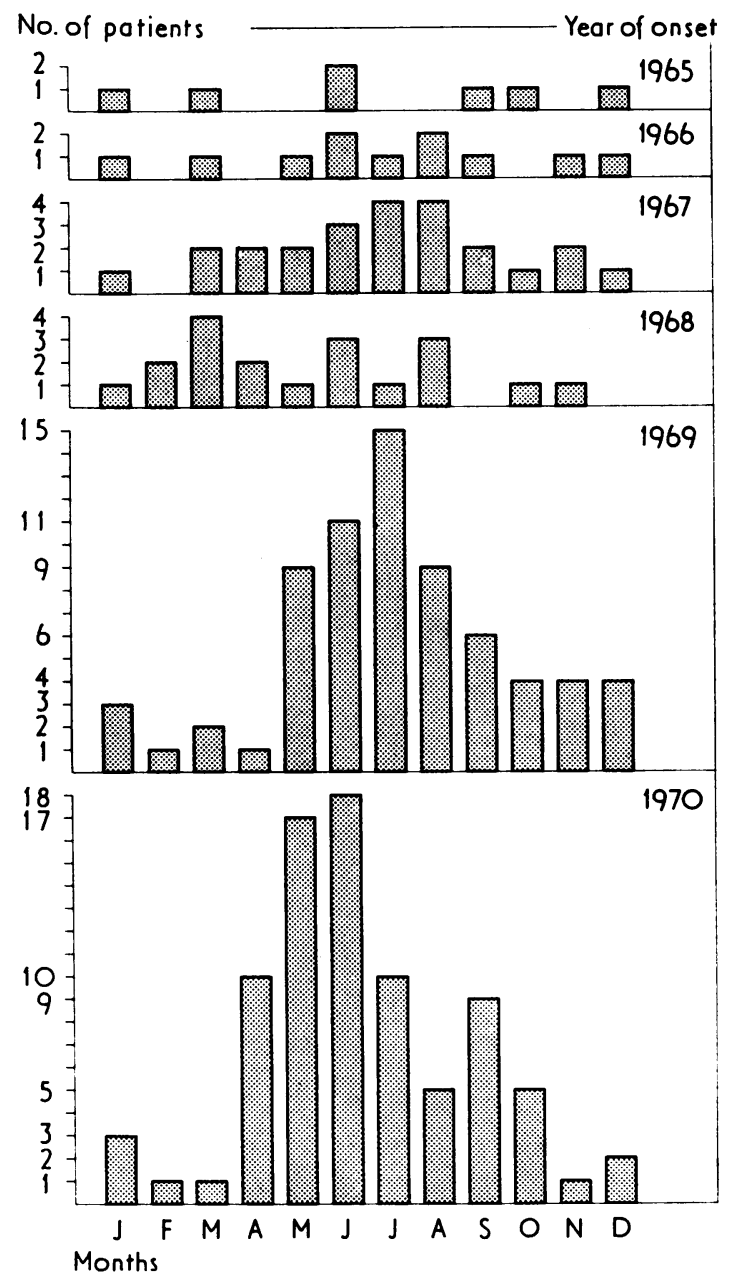

FIG. 4.-Annual and seasonal distribution of 212 children with the haemolytic-uraemic syndrome 1965-1970.

others (Fluge and Moe, 1967; Lieberman, 1972). The number of cases detected in the Netherlands remained approximately constant from 1969-1972 (data from our own clinic and others).

The illness appeared mainly in infancy, but has also been described as occurring in older children and in adults (Clarkson et al., 1970; Shapiro et al., 1970). The number of patients in our group older than 4 years was small and thereafter there is a progressive decline in incidence. This age distribution may be important in relation to the aetiology of the illness.

At the moment it is well known that the disease in most cases begins with a 'gastroenteritis' (Gianantonio et al., 1967; Piel and Phibbs, 1966), 
though this is not the case in the children described in France (Mathieu et al., 1969). The initial phase may start suddenly with abdominal pain, and intussusception may be suspected (Berman, 1972; Maki, Miyata, and Uda, 1968); the blood picturewith the typical red cell fragmentation-is then of great help in diagnosis.

We found, in contrast to other authors (Gianantonio et al., 1968; Mathieu et al., 1969), that neurological disturbances were present only as complications (Lieberman, 1972). Several cases followed a mild course, so that it is possible that HUS may be more frequent than is indicated in this communication.

The microbial investigations of the 212 patients lent no support to the idea that the disease is caused by a bacterial infection (Brain, 1969; Gianantonio et al., 1964; Kaplan and Koornhof, 1969; McLean et al., 1966; Ray et al., 1970). No Microtatobiote was seen in the blood films (Mettler, 1969). Noticeable was the variety of viral agents that were isolated. Some authors consider viruses as possible causes (Brain, 1969; Gianantonio et al., 1964, 1968; Glasgow, and Balduzzi, 1965; Mathieu et al., 1969; Piel and Phibbs, 1966; Austin and Ray, 1973), and it is well known that viruses may cause intravascular coagulation (Gagel et al., 1970; McKay and Margaretten, 1967; Yoshikawa, Tanaka, and Guze, 1971).

Concerning the seasonal influence (Gianantonio et al., 1964; Mathieu et al., 1969; Ray et al., 1970), despite the greater number of cases in the late spring and early summer of 1969 and 1970 in the Netherlands, the National Institute for Public Health noted no virus epidemics in the years 1969 and 1970. Normally this period of the year in the Netherlands is characterized by a high incidence of virus isolation in the population.

The fact that the disorder occurs most frequently in late spring and early summer, gastroenteritis occurs in other family members, and there is an incidence of HUS in sibs and in small clusters, all suggest an infective, probably viral, aetiology.

\section{REFERENCES}

Anthony, P. P., and Kaplan, A. B. (1968). Fatal haemolyticuraemic syndrome in two sibs. Archives of Disease in Childhood, 43, 316.

Austin, T. W., and Ray, C. G. (1973). Coxsackie virus group B infections and the hemolytic-uremic syndrome. Fournal of Infectious Diseases, 127, 698.

Avalos, J. S., Vitacco, M., Molinas, F., Peñalver, J., and Gianantonio, C. (1970). Coagulation studies in the hemolyticuremic syndrome. Fournal of Pediatrics, 76, 538 .

Barnard, P. J., and Kibel, M. (1965). The hemolytic-uremic syndrome of infancy and childhood. A report of eleven cases. Central African fournal of Medicine, 11, 31.

Berman, W., Jr. (1972). The hemolytic-uremic syndrome: initial clinical presentation ulcerative colitis. Fournal of Pediatrics, 81 , 275.
Brain, M. C. (1969). The hemolytic-uremic syndrome. Seminars in Hematology, 6, 162.

Campbell, S., and Carré, L. J. (1965). Fatal haemolytic uraemic syndrome and idiopathic hyperlipaemia in monozygotic twins. Archives of Disease in Childhood, 40, 654.

Clarkson, A. R., Lawrence, J. R., Meadow, R., and Seymour, A. E. (1970). The haemolytic uraemic syndrome in adults. Quarterly fournal of Medicine, 39, 227.

Davies, P. (1968). The haemolytic-uraemic syndrome. East African Medical fournal, 45, 136.

Dosik, H., and Tricarico, F. (1970). Haemolytic-uraemic syndrome following mumps vaccination. Lancet, 1, 247.

Fluge, G., and Moe, P. J. (1967). Hemolytic-uremic (nephropathic) syndrome. A clinical picture unrecognized in the past? Acta Paediatrica Scandinavica, 56, 665.

Gagel, C., Linder, M., Müller-Berghaus, G., and Lasch, H. G. (1970). Virus infection and blood coagulation. Thrombosis et Diathesis Haemorrhagica, 23, 1.

Gasser, C., Gautier, E., Steck, A., Siebenman, R. E., and Oechslin, R. (1955). Hämolytisch-urämische Syndrome: Bilaterale Nierenrindennekrosen bei akuten erworbenen hämolytischen Anämien. Schweizerische Medizinische Wochenschrift, 85, 905.

Gianantonio, C., Vitacco, M., and Mendilaharzu, F. (1967). The hemolytic-uremic syndrome. In Proceedings of the Third International Congress of Nephrology, Vol. 3, p. 24. Ed. by G. E. Schreiner. Karger, Basle and New York.

Gianantonio, C. A., Vitacco, M., Mendilaharzu, F., and Gallo, G. (1968). The hemolytic-uremic syndrome. Renal status of 76 patients at long-term follow-up. Fournal of Pediatrics, 72, 757.

Gianantonio, C., Vitacco, M., Mendilaharzu, F., Rutty, A., and Mendilaharzu, J. (1964). The hemolytic-uremic syndrome. Fournal of Pediatrics, 64, 478.

Glasgow, L. A., and Balduzzi, P. (1965). Isolation of Coxsackie virus group $A$, type 4 , from a patient with hemolytic-uremic syndrome. New England fournal of Medicine, 273, $7 j 4$.

Habib, R., Mathieu, H., and Royer, P. (1967). Le syndrome hémolytique et urémique de l'enfant. Nephron, 4, 139.

Kaplan, B. S., Katz, J., Krawitz, S., and Lurie, A. (1971). An analysis of the results of therapy in 67 cases of the hemolyticuremic syndrome. Fournal of Pediatrics, 78, 420 .

Kaplan, B. S., and Koornhof, H. J. (1969). Haemolytic-uraemic syndrome: failure to demonstrate circulating endotoxin. Lancet, 2, 1424.

Kibel, M. A., and Barnard, P. J. (1968). The haemolytic-uraemic syndrome: a survey in Southern Africa. South African fournal of Medicine, 42, 692.

Lieberman, E. (1972). The hemolytic-uremic syndrome. fournal of Pediatrics, 80, 1.

McKay, D. G., and Margaretten, W. (1967). Disseminated intravascular coagulation in virus diseases. Archives of Internal Medicine, 120, 129.

McLean, M. M., Hilton Jones, C., and Sutherland, D. A. (1966) Haemolytic-uraemic syndrome. A report of an outbreak. Archives of Disease in Childhood, 41, 76.

Maki, S., Miyata, H., and Uda, H. (1968). Hemolytic-uremic syndrome. A fatal case after operation for intussusception as a complication of upper respiratory tract infection. Medical Fournal of the Osaka University, 19, 157.

Mathieu, H., Leclerc, F., Habib, R., and Royer, P. (1969). Etude clinique et biologique de 37 observations de syndrome hémolytique et uremique. Archives Françaises de Pédiatrie, 26, 369.

Mettler, N. E. (1969). Isolation of a microtatobiote from patients with hemolytic-uremic syndrome and thrombotic thrombocytopenic purpura and from mites in the United States. New England Fournal of Medicine, 281, 1023.

Monnens, L., Kleynen, F., van Munster, P., Schretlen, E., and Bonnerman, A. (1972). Coagulation studies and streptokinase therapy in the haemolytic-uraemic syndrome. Helvetica Paediatrica Acta, 27, 45.

Olson, L. C., Bourgeois, C. H., Jr., Cotton, R. B., Harikul, S., Grossman, R. A., and Smith, T. J. (1971). Encephalopathy and fatty degeneration of the viscera in Northeastern Thailand. Pediatrics, 47, 707.

Piel, C. F., and Phibbs, R. H. (1966). The hemolytic-uremic syndrome. Pediatric Clinics of North America, 13, 295. 
Ray, C. G., Tucker, V. L., Harris, D. J., Cuppage, F. E., and Chin, T. D. Y. (1970). Enteroviruses associated with the hemolyticuremic syndrome. Pediatrics, 46, 378.

Rubin, M. I. (1964). Systemic hypertension. Pediatric Clinics of North America, 11, 431.

Ruthven, I. S., and Fyfe, W. M. (1968). The haemolytic uraemic syndrome: an epidemic disease? Scottish Medical fournal, 13, 162.

Shapiro, C. M., Kanter, A., Lopas, H., and Rabiner, S. F. (1970). Hemolytic-uremic syndrome in adults. Fournal of the American Medical Association, 213, 567.
Wolman, M. (1972). Etiology and pathogenesis of the hemolyticuremic syndrome. Israel fournal of Medical Sciences, 8, 984.

Yoshikawa, T., Tanaka, K. R., and Guze, L. B. (1971). Infection and disseminated intravascular coagulation. Medicine, 50, 237.

Correspondence to Dr. P. M. V. van Wieringen, Paediatric Department, Sint Radboudziekenhuis, Nijmegen, The Netherlands.

The following articles will appear in future issues of this journal:

Personal practice: Management of newborn babies in whom serious metabolic illness is anticipated. D. M. Danks. Histidinaemia in mouse and man. G. Bulfield and H. Kacser.

Chronic suppurative lung disease in sisters mimicking cystic fibrosis. J. J. Cogswell, R. A. Risdon, and B. Taylor. Intrarenal reflux and the scarred kidney. G. L. Rolleston, T. M. J. Maling, and C. J. Hodson.

Antibodies to Epstein-Barr and other viruses in children with acute lymphoblastic leukaemia. $R$. N. P. Sutton, S. D. Marston, H. J. M. Pullen, C. W. Darby, D. I. K. Evans, and R. T. D. Emond.

Improved prognosis of infants mechanically ventilated for hyaline membrane disease. $E$. $O$. R. Reynolds and A. Taghizadeh.

Minimal rates of oxygen consumption in small-for-dates babies during first week of life. $O$. N. Bhakoo and J. W. Scopes.

Prolonged continuous positive airways pressure for pulmonary oedema due to persistent ductus arteriosus in the newborn. N.R. C. Roberton. 